\title{
Profitability of insect farms
}

\author{
H.H. Niyonsaba", J. Höhler, J. Kooistra, H.J. Van der Fels-Klerx and M.P.M. Meuwissen \\ Business Economics Group, Wageningen University, P.O. Box 8130, 6700 EW Wageningen, the Netherlands; \\ hilde.niyonsaba@wur.nl
}

Received: 23 July 2020 / Accepted: 22 December 2020

(c) 2021 Wageningen Academic Publishers

OPEN ACCESS C(1) R(2) REVIEW ARTICLE

\begin{abstract}
Despite growing interest from entrepreneurs, knowledge on the profitability of commercial-scale insect production is scarce. Insight into the economic figures of insect production is needed by farmers aiming to start insect farms, by banks seeking to provide financing, and by governments planning policy interventions. This review provides an overview of the profitability and underlying economic figures relating to the production of Hermetia illucens, Alphitobius diaperinus, Tenebrio molitor and Acheta domesticus. To enhance data interpretation, we also provide a brief overview of the global insect sector, with specific attention to farm-level operational practices. Sales prices refer to fresh larvae, dried larvae or larvae meal, whereas operational costs include costs for feed, labour, electricity, water and gas. Operational cost components differ per insect species, and therefore the relevant margins are specified for three insect species. The energy, feed, and labour margin for production of $H$. illucens ranges from $€-798$ to 15,576 per tonne of dried larvae. The feed and labour margin for production of T. molitor ranges from $€ 7,620$ to 13,770 per tonne of fresh larvae. For production of $A$. domesticus the feed margin ranges from $€ 12,268$ to 78,676 per tonne of larvae meal. The margin range for A. diaperinus cannot be estimated, due to a lack of data in the literature. The ranges mainly reflect the differences in sales prices, which are found to heavily depend on the geographical market location, type of market (feed or food) and quantity sold. Major operational costs include feed and labour, with feed costs varying substantially within and between insect species. The economic figures and margins presented in this article provide a foundation for the further development of the insect production sector.
\end{abstract}

Keywords: insect production, farming, edible insects, economics, H. illucens, A. diaperinus, T. molitor, A. domesticus, sales prices, costs

\section{Introduction}

The production of insects is promising from the perspective of both food security and sustainability (Aiking and de Boer, 2019), and it is believed that insects can fill at least part of the projected protein gap (Henchion et al., 2017). For farmers to start producing insects, however, insight is needed into the profitability and underlying economic figures of insect production. If it is not profitable, farmers are not likely to switch to insect production or to start insect farms; banks will not be eager to provide financing, and actors within the value chain will also hesitate to invest (Hillier et al., 2016). Government officials and scientists also need insight into farm costs and margins for policy interventions and further empirical research.
The insect sector distinguishes itself from existing agricultural sectors by its young and dynamic nature and the proliferation of small-scale farms ${ }^{1}$ (Derrien and Boccuni, 2018; Marberg et al., 2017). Given that each insect species is unique, with specific farming requirements, a species-specific approach is needed (Heckmann et al., 2019). The European insect sector is in a developmental stage. Although there are some large farms, the majority is still operating on a small scale (Mancuso et al., 2019). To date, most research has focused on the technical aspects of insect production, such as food safety and quality (Van der

\footnotetext{
${ }^{1}$ Due to scale differences in the insect sector the terms 'farms', 'companies' and 'businesses' are used interchangeably in this article, with the latter relating primarily to large-scale production facilities.
} 
Fels-Klerx et al., 2018), nutritional values (Roos and Van Huis, 2017), production and processing practices (Rumpold and Schlüter, 2013) and environmental benefits (Oonincx, 2017). Knowledge concerning the profitability of insect production remains scarce.

This study intends to provide a comprehensive overview of the profitability of insect production and underlying economic figures. It includes an analysis of peer-reviewed articles and other literature on costs and prices involved in the production of the following insect species: Hermetia illucens (black soldier fly), Tenebrio molitor (yellow mealworm), Alphitobius diaperinus (lesser mealworm), and Acheta domesticus (house cricket). These four species are amongst the species that have received the most interest within the context of insect production in the Western world in recent decades (Van Huis, 2020). To enhance data interpretation, Section 2 provides an overview of the current status of insect production globally, with specific attention to the European insect sector and its operational practices. We focus on the European context, due to its high potential for sustainable protein provision and its growing commercial insect industry (Aiking and De Boer, 2019). The literature search strategy and data processing approach are presented in Section 3, followed by the literature results (Section 4), including an overview of sales prices ${ }^{2}$ and costs of insect production, as well as estimated margin ranges. We present sales prices only for products produced in compliance with EU legislative requirements or comparable, including results from China, Egypt, Kenya and Thailand. For example, data from farms using human excreta as feed are excluded, as this practice is not allowed in the EU. Because the literature review is based on data that have been sourced in different ways, Section 4 also provides details on the research approach and context. The article ends with a general discussion and conclusions (Section 5).

\section{The global insect sector and European operational production practices}

In some parts of the world, especially in the tropics, insects are caught in the wild and have been part of human diets for a long time (Marcucci, 2020). Since it became clear that insects could also be reared on larger scale to serve as a protein source for feed and food, commercial insect production has been receiving additional interest. Insects are already being produced commercially in many parts of the world, with regional variations in insect species, scale of production and farm types - as well as in insect-eating habits. For example, insects are commonly reared and consumed on both larger and smaller scales in Asia, Africa and Latin America (Kelemu et al., 2015; Raheem et al.,

\footnotetext{
${ }^{2}$ Sales prices refer to both output prices and retail prices.
}

2019). In the past decade, the number of farms producing insects on a larger scale has been increasing in America and Europe as well, with the former focusing on $A$. domesticus and the latter producing mainly $H$. illucens and T. molitor. These Western insect industries were initiated largely by entrepreneurial companies, many of which have obtained financial support through crowdfunding campaigns and large investors (Dossey et al., 2016). In addition, many small enterprises are selling their insect products in niche markets as specialty items (Macombe et al., 2019). The International Platform for Food and Feed (IPIFF), a non-profit organisation based in the EU, reports that its members have raised $€ 600$ million for investments in insect production through September 2019, and that its members are already producing 6,000 tonnes of insects for food and feed each year. Production could reach up to five million tonnes by 2030 (IPIFF, 2019). It has even been predicted that the global insect feed market will reach a value of USD 1.4 billion by 2024 (Research and Markets, 2019). In Europe, insects are produced mostly as a protein ingredient for fish feed and pet food, as these are the applications that are currently allowed under European law (Sogari et al., 2019). Expected relaxations in European legislation are likely to include allowing the incorporation of insect proteins in pig and chicken feed, thereby increasing both the demand for and the number of insect-based feeds. The current growth in the insect-feed market is accompanied by increased interest in the use of insects for food in Europe (IPIFF, 2020a). IPIFF (IPIFF, 2019) indicates that aquaculture absorbs more than half of the insect production. For the other market segments no market shares could be found.

To date, the majority of Western insect farms are quite small, with much less technology and mechanisation than other agricultural farms (Dossey et al., 2016). In terms of operations, European insect farms generally have two separate production units: one for the maintenance of breeding colonies and another one for the production of larvae from the eggs (Halloran et al., 2018). Many insect farms also perform first-step processing after harvesting the insects by drying them. An additional unit is needed for farms that also capture maturing of insects (as is the case for A. domesticus). In general, the indoor nature of insect production presents an ideal opportunity for farms to specialise rather than doing all aspects of the insect production steps themselves (Dossey et al., 2016). There are roughly three different business set-ups for insect farms: (1) farms that purchase eggs or small larvae from a supplier and focus on the fattening and, if relevant, the further maturation of the larvae; (2) farms that cover the entire production process, from laying eggs to harvesting and the first-processing (i.e. drying) of larvae; and (3) large-scale production facilities, which cover all steps of the production of insect larvae, as well as further processing steps (e.g. milling, de-fattening and the fractioning of proteins or 
fats). This literature review focuses on insect production and the processing steps drying and milling, and not on further processing (i.e. de-fattening meal or fractioning of proteins or fats) for incorporation of insect produce into feed or food.

The material and machine inputs required for an insect farm depend on the level of mechanisation. Basic inputs include the plastic trays in which insects are reared and fed. Depending on the level of mechanisation, these inputs can also include drying machines (Pleissner and Smetana, 2020), conveyor belts for internal transport, and continuous feeding systems (Ites et al., 2020). Operational inputs are divided into material input and labour. Within the category of material inputs, the feed for insects is generally regarded as a main component, given that the quality and composition of feed has a substantial influence on the growth of insects and the quality of the end product (Jensen et al., 2017). Furthermore, the production environment is a crucial factor for the survival and growth of insects (Rumpold and Schlüter, 2013). For this reason, the material inputs of insect farms also include the energy and water used for insect production, as well as for firststep and further processing (Ortiz et al., 2016). Another important operational input is labour, given the highly labour-intensive character of insect farms, and especially the current small-scale, largely non-mechanised insectproduction process (Meuwissen, 2011). More specifically, the majority of the farms operate largely with manual production systems for the feeding, housing, harvesting and cleaning of insects (Dobermann et al., 2017; Rumpold and Schlüter, 2013).

With regard to the output of insect farms, the main product types include small larvae, grown larvae and mature insects. The processing formats for these products include fresh larvae and dried larvae. Larger production facilities also produce insect meal, which requires further processing. Insect frass is also regarded an important output in terms of volume, but is not yet commercialised on the European market. Additionally, the regulatory framework is 'fragmented' and often restricts insect farmers from upcycling insect frass to high quality fertiliser (IPIFF, 2020b).

\section{Literature search strategy and approach}

\section{Search strategy}

The literature search initially focused on peer-reviewed articles published in the period 2010 -May 2020 in three databases: Scopus, CAB Abstracts and Web of Science. Search strings were pre-defined and included the following: 'black soldier fly' OR 'Hermetia illucens' OR 'lesser mealworm' OR 'Alphitobius diaperinus' OR 'yellow mealworm' OR 'Tenebrio molitor' OR 'cricket'
OR 'A. domesticus' AND 'feed OR food' AND 'financ ${ }^{*}$ ' OR 'econom*'. An additional constraint was added for A. domesticus: AND NOT 'bean'.

The articles obtained through the search were screened for relevance according to selection criteria. First, to be included, a paper had to contain relevant economic quantitative data (e.g. economic figures on operational costs or sales prices for insect production). Second, the production system investigated had to focus on the commercial production of insects for food or feed, and not for cosmetics or medicines. Third, the production processes addressed were required to comply with EU regulations, or at least fulfil similar conditions (e.g. insects should not be fed on human or animal waste streams). Fourth, the article had to be written in either English or Dutch. No limitation was set on the geographical area in which the study had been performed, as long as production circumstances were compatible with the European context.

Due to the relatively low number of hits from refereed databases, snowballing was used to identify additional resources. Snowballing implies using the references of retrieved papers to identify additional papers relevant to our study aims. The initial hits obtained from refereed databases and snowballing are listed in Table 1 and their data are discussed below. For H. illucens, six peer-reviewed articles and one report were included in the analysis. The search for $A$. diaperinus led to the inclusion of one report and two non-peer-reviewed articles. For T. Molitor, three peer-reviewed articles and one report were analysed. The search for $A$. domesticus led to the inclusion of five peerreviewed articles and one market-analysis report.

\section{Processing retrieved data}

The economic structure of a business (e.g. an insect farm) can be divided into three main components: operations (with gross margin as a key figure), investments (for which capital expenditures are an important parameter) and financing in the form of debt and equity (Brealey, 2001). Given the scarcity of data on the capital costs of and sources of financing for actual insect farms, this review further focused on operational costs, with operational inputs divided into production-related material costs and labour. Sales prices were specified for three processing formats, differing in dry matter contents of insect products: fresh larvae, dried larvae and larvae meal. Also, the end-market (i.e. feed, pet food, and human consumption) for each sales price was identified. Insect frass was not included in this review, since the use of insect frass as fertiliser on a commercial level is impeded by the lack of a harmonised EU regulatory framework (IPIFF, 2020b). All costs and sales prices were recalculated into euros, applying an exchange rate of $1 / 1.10$ (EUR/USD), as retrieved on 28 May 2020 (Investing.com, 2020), and presented in EUR (€) 
Table 1. Initial hits and final number of articles and other sources included.

\begin{tabular}{lcccc} 
Number of refereed articles after initial search & Insect species & & \\
\cline { 2 - 5 } & Hermetia illucens & Alphitobius diaperinus & Tenebrio molitor & Acheta domesticus \\
\cline { 2 - 5 } & & & & 32 \\
SCOPUS & 57 & 6 & 24 & 43 \\
CAB Abstracts & 84 & 17 & 15 & 10 \\
$\quad$ (overlap with SCOPUS) & 34 & 4 & 31 & 18 \\
Web of science & 58 & 8 & 18 & 68 \\
$\quad$ (overlap with SCOPUS) & 42 & 22 & 86 & 5 \\
Total number of unique articles & 123 & 0 & 3 & 15 \\
Number of refereed articles included & 6 & 2 & 1 & 1
\end{tabular}

per tonne of product. If the costs and prices in an article were not expressed as $€ /$ tonne, we calculated these from the data given in the article. Margins for each insect species were calculated based on the sales prices and averages of operational costs per tonne of product across the references available.

For example, for each tonne of larvae, we used the following equation:

Margin per tonne of larvae $=$ sales price per tonne of larvae - average operational costs per tonne of larvae

Since sales prices differed considerably between endmarkets, while cost components were comparable within the different insect species, margins were calculated based on sales prices and average operational costs. Based on the availability of information on operational costs, three different margins were specified: energy, feed, and labour margin for production of dried H. illucens larvae, feed and labour margin for production of fresh T. molitor larvae, and feed margin for production of $A$. domesticus meal. These margins were combined into a margin range for the different insect species, with the range mainly expressing the variety in sales prices related to different end-markets.

\section{Profitability of insect production}

Economic figures for the production of H. illucens, A. diaperinus, T. molitor and A. domesticus are presented in Table 2-5. The sources are listed in these tables, along with their research contexts, including country, study method, underlying source of the economic figures and targeted end-market (i.e. feed, pet food, or human consumption). All included studies were conducted in an experimental or normative modelling context. In other words, none of the studies presents factual data on operational costs from operating farms. With regard to sales prices, the process presented in most of the studies are based on retail prices or personal communications. In addition, most of the studies focus on topics other than economics. Sales prices are investigated primarily within the context of feeding trials or consumer-acceptance studies. The economic figures presented in Table 2-5 include sales prices for the various processing formats. Operational costs include feed, water, electricity, labour and gas. In the following sections, we provide details on all four insect species, starting with sales prices, and followed by operational costs. Estimated margins and their ranges are presented in Table 6 in the last section.

\section{Profitability of Hermetia illucens production}

Economic figures for the production of $H$. illucens from the selected studies are presented in Table 2. Reported sales prices for dried H. illucens larvae vary considerably, ranging from $€ 1,816$ to $€ 18,900$ per tonne of product. All of these sales prices are based on retail prices from around 2018, although they differ according to the type of market in which they were sold. For example, the sales price for $H$. illucens larvae sold in small quantities for pet food ( $€ 18,190$ per tonne of product) is very high, compared to the others in the same category. The authors describe this price as not so realistic, compared to another sales price mentioned in the article and ascribe it to the small quantity sold (Ites et al., 2020). Sales prices for larvae meal range from $€ 427$ to $€ 5,091$ per tonne of product. Sales prices in Egypt and Kenya are low, which could be explained by inter alia the low operational costs in these countries. In one study (Llagostera et al., 2019), the authors explain a reduction in sales prices between 2016 and 2018 in terms of increased competition over time. Sales prices for fresh larvae (i.e. not dried or processed) - ranging from $€ 2,000$ to $€ 3,000$ per tonne of product - are obtained from only one report (Hilkens et al., 2016). Contrary to reported observations, fresh larvae could be expected to have the lowest sales price, as they require no additional processing steps. 
Table 2. Research context and economic figures for Hermetia illucens production.

\begin{tabular}{|c|c|c|c|c|c|c|c|c|}
\hline \multirow{2}{*}{$\begin{array}{l}\text { Source } \\
\text { Refereed } \\
\text { literature }\end{array}$} & \multicolumn{4}{|c|}{ Research context } & \multicolumn{3}{|c|}{ Price ( $€ /$ tonne of product) } & \multirow[t]{2}{*}{$\begin{array}{l}\text { Operational } \\
\text { costs ( } € / \text { tonne of } \\
\text { dried larvae) })^{2}\end{array}$} \\
\hline & Country & Study method & $\begin{array}{l}\text { Underlying source of } \\
\text { economic figures }\end{array}$ & $\begin{array}{l}\text { Targeted } \\
\text { end-market }\end{array}$ & $\begin{array}{l}\text { Dried } \\
\text { larvae }^{1}\end{array}$ & $\begin{array}{l}\text { Larvae } \\
\text { meal }\end{array}$ & $\begin{array}{l}\text { Fresh } \\
\text { larvae }\end{array}$ & \\
\hline $\begin{array}{l}\text { Abdel-Tawwab et } \\
\text { al., } 2020\end{array}$ & Egypt & $\begin{array}{l}\text { Feeding trial to } \\
\text { implement larvae meal }\end{array}$ & Local market prices 2020 & feed & $\mathrm{n} / \mathrm{a}$ & 427 & $\mathrm{n} / \mathrm{a}$ & $\mathrm{n} / \mathrm{a}$ \\
\hline Chia et al., 2019 & Kenya & $\begin{array}{l}\text { Feeding trial to } \\
\text { implement larvae meal }\end{array}$ & Local market prices 2019 & feed & $\mathrm{n} / \mathrm{a}$ & 464 & $\mathrm{n} / \mathrm{a}$ & $\mathrm{n} / \mathrm{a}$ \\
\hline \multirow[t]{3}{*}{ Ites et al., 2020} & Germany & $\begin{array}{l}\text { Modular system design } \\
\text { and economic analysis } \\
\text { of three different types } \\
\text { of food wastes for insect } \\
\text { production, applied to } \\
\text { German conditions }\end{array}$ & $\begin{array}{l}\text { Retail price Illucens GmbH } \\
\text { (2018) }\end{array}$ & pet food & $18,190^{\mathrm{a}}$ & $\mathrm{n} / \mathrm{a}$ & $\mathrm{n} / \mathrm{a}$ & $\mathrm{n} / \mathrm{a}$ \\
\hline & & & $\begin{array}{l}\text { Estimated price based on } \\
\text { hypothetical farm design } \\
\text { ( } 24.51 \text { tonnes of dry } \\
\text { larvae/year) }\end{array}$ & $\mathrm{n} / \mathrm{a}$ & $\mathrm{n} / \mathrm{a}$ & $\mathrm{n} / \mathrm{a}$ & $\mathrm{n} / \mathrm{a}$ & $\begin{array}{r}1,760^{\mathrm{c}} ; 317^{\mathrm{d}, \mathrm{h}} ; \\
1,274^{\mathrm{e}, \mathrm{i}} ; 426^{\mathrm{f}, \mathrm{j}}\end{array}$ \\
\hline & & & $\begin{array}{l}\text { Retail price Illucens GmbH } \\
\text { (2018) }\end{array}$ & pet food & $6,500^{b}$ & $\mathrm{n} / \mathrm{a}$ & $\mathrm{n} / \mathrm{a}$ & $\mathrm{n} / \mathrm{a}$ \\
\hline \multirow[t]{2}{*}{$\begin{array}{l}\text { Llagostera et al., } \\
2019\end{array}$} & Spain & $\begin{array}{l}\text { Discrete choice } \\
\text { experiment to assess } \\
\text { preferences of } 215 \\
\text { Spanish consumers } \\
\text { on the incorporation } \\
\text { of insect meal into fish } \\
\text { feed }\end{array}$ & $\begin{array}{l}\text { Personal communication } \\
\text { (2016) }\end{array}$ & $\mathrm{n} / \mathrm{a}$ & $\mathrm{n} / \mathrm{a}$ & 5,091 & $\mathrm{n} / \mathrm{a}$ & $\mathrm{n} / \mathrm{a}$ \\
\hline & & & $\begin{array}{l}\text { Personal communication } \\
\text { Entomb Agrolndustrial } \\
\text { Platform (2018) }\end{array}$ & $\mathrm{n} / \mathrm{a}$ & $\mathrm{n} / \mathrm{a}$ & 2,273 & $\mathrm{n} / \mathrm{a}$ & $\mathrm{n} / \mathrm{a}$ \\
\hline \multirow[t]{2}{*}{$\begin{array}{l}\text { Mancuso et al., } \\
2019\end{array}$} & Italy & $\begin{array}{l}\text { SWOT analysis of } \\
28 \text { European insect } \\
\text { companies }\end{array}$ & $\begin{array}{l}\text { Personal communication } \\
\text { with an EU company } \\
\text { Nextalim }\end{array}$ & feed & $\mathrm{n} / \mathrm{a}$ & 2,000 & $\mathrm{n} / \mathrm{a}$ & $\mathrm{n} / \mathrm{a}$ \\
\hline & & & $\begin{array}{l}\text { Based on personal } \\
\text { communication } \\
\text { (L. Gasco, 2018) }\end{array}$ & $\mathrm{n} / \mathrm{a}$ & 2,500 & $\mathrm{n} / \mathrm{a}$ & $\mathrm{n} / \mathrm{a}$ & $\mathrm{n} / \mathrm{a}$ \\
\hline \multirow[t]{2}{*}{$\begin{array}{l}\text { Pleissner and } \\
\text { Smetana, } 2020\end{array}$} & Germany & $\begin{array}{l}\text { Economic feasibility } \\
\text { analysis of hypothetical } \\
\text { design for insect } \\
\text { production }\end{array}$ & $\begin{array}{l}\text { Retail market price (place } \\
\text { and year n/a) }\end{array}$ & $\mathrm{n} / \mathrm{a}$ & 1,816 & $\mathrm{n} / \mathrm{a}$ & $\mathrm{n} / \mathrm{a}$ & $\mathrm{n} / \mathrm{a}$ \\
\hline & & & $\begin{array}{l}\text { Estimated price based on } \\
\text { hypothetical farm design } \\
(1,092 \text { tonnes of dried } \\
\text { larvae per year) }\end{array}$ & $\mathrm{n} / \mathrm{a}$ & $\mathrm{n} / \mathrm{a}$ & $\mathrm{n} / \mathrm{a}$ & $\mathrm{n} / \mathrm{a}$ & $\begin{array}{c}21^{\mathrm{c}} ; 160^{\mathrm{d}, \mathrm{l}} ; 126^{\mathrm{e}, \mathrm{l}} ; \\
135^{\mathrm{f}, \mathrm{m}} ; 1,00 \mathrm{~g}^{\mathrm{g}, \mathrm{n}}\end{array}$ \\
\hline \multicolumn{9}{|l|}{ Other } \\
\hline $\begin{array}{l}\text { Hilkens et al., } \\
2016\end{array}$ & Netherlands & Market-analysis report & $\begin{array}{r}\text { Company data } \\
\text { (Protix, 2015) }\end{array}$ & pet food & $\mathrm{n} / \mathrm{a}$ & $\mathrm{n} / \mathrm{a}$ & $\begin{array}{r}2,000- \\
3,000\end{array}$ & $\mathrm{n} / \mathrm{a}$ \\
\hline
\end{tabular}


Only two articles report on operational costs for dried $H$. illucens larvae. One study estimates costs for H. illucens production in Germany based on a hypothetical design for an insect production facility. The other study also suggests a hypothetical (modular) design system within the German context. The large differences between the two articles with regard to operational costs per tonne of product could be explained as follows. First, the costs per unit for water, electricity and labour differ considerably. This could be related to the production volume, which is higher for the design with the lower operational costs per tonne of product. Second, the designs differ in terms of feed costs. Pleissner and Smetana (2020) report that their low feed costs include only a fee that might possibly be charged for the treatment of food waste, in addition to transport and collection costs. In contrast, Ites et al. (2020) also account for the costs of the feed itself. Although the authors provide no information on the quality of feed, it is known that the optimal conditions and type of food waste used to produce $H$. illucens have a major impact on factors that increase both profitability (e.g. the growing time of the larvae) and the quality of the product (Law and Wein, 2018).

\section{Profitability of Alphitobius diaperinus production}

Economic figures for the production of $A$. diaperinus are presented in Table 3. The number of articles is low, and the sales prices reported represent different processing formats. The three-fold price difference between fresh larvae and larvae meal could be explained by the higher dry-matter content of meal as compared to fresh product. Moreover, additional processing steps are needed to produce larvae meal. The high sales price for freeze-dried $A$. diaperinus reported by Meuwissen (2011) was originally sourced from a website advertising such products as delicacies for human consumption, where they were likely sold in small quantities with a high standard of quality.

\section{Profitability of Tenebrio molitor production}

Economic figures for the production of T. molitor are presented in Table 4. Reported sales prices for T. molitor larvae range from $€ 5,727$ to $€ 97,000$ per tonne of product. The low sales prices originating from China could be explained by the well-developed market in China, where T. molitor is produced industrially for food and feed, for both domestic use and export (Llagostera et al., 2019). The low price could also be related to economies of scale, as a larger production scale often implies a higher level of mechanisation and lower labour costs (Ortiz et al., 2016). The European retail price obtained from Ortiz et al. (2016) includes only dried T. molitor larvae dedicated to human consumption, thus possibly explaining the higher sales prices for Europe. A high sales price of $€ 97,000$ per tonne of dried larvae could be explained by the high quality of the product sold in retail. Sales prices for fresh T. molitor larvae range from $€ 10,850$ to $€ 17,000$ per tonne of product. The price difference observed between 2011 (Meuwissen, 2011) and 2019 (Mancuso et al., 2019) might be related to the increasing competition and/or technical progress within the insect sector. The difference in sales prices from one source reported in Mancuso et al. (2019) is related to the processing format, as the larvae with higher sales prices are sold in frozen form.

With regard to the operational costs for fresh T. molitor, only feed and labour costs could be obtained, and from only one report. The labour costs of $€ 2,140$ per tonne of product mentioned in this report are comparatively high, and the author attributes them to the low level of mechanisation in insect production, which further implies low productivity (Meuwissen, 2011).

Table 3. Research context and economic figures for Alphitobius diaperinus production.

\begin{tabular}{|c|c|c|c|c|c|c|c|c|}
\hline \multirow{2}{*}{$\begin{array}{l}\text { Source } \\
\text { Other }\end{array}$} & \multicolumn{4}{|c|}{ Research context and set-up } & \multicolumn{3}{|c|}{ Price ( $€ /$ tonne of product) } & \multirow{2}{*}{$\begin{array}{l}\text { Operational } \\
\text { costs ( } € / \text { tonne } \\
\text { of dried larvae }\end{array}$} \\
\hline & Country & Study method & $\begin{array}{l}\text { Underlying source } \\
\text { of economic figures }\end{array}$ & $\begin{array}{l}\text { Targeted end- } \\
\text { market }\end{array}$ & $\begin{array}{l}\text { Dried } \\
\text { larvae }^{1}\end{array}$ & $\begin{array}{l}\text { Larvae } \\
\text { meal }\end{array}$ & $\begin{array}{l}\text { Fresh } \\
\text { larvae }\end{array}$ & \\
\hline $\begin{array}{l}\text { Hilkens et } \\
\text { al., } 2016\end{array}$ & Netherlands & Market-analysis report & $\begin{array}{l}\text { Company data } \\
\text { (Protifarm, 2016) }\end{array}$ & pet food & $\mathrm{n} / \mathrm{a}$ & 15,000 & $\mathrm{n} / \mathrm{a}$ & $\mathrm{n} / \mathrm{a}$ \\
\hline \multirow[t]{2}{*}{$\begin{array}{l}\text { Meuwissen, } \\
2011\end{array}$} & Netherlands & Market-analysis report & $\begin{array}{l}\text { Retail price } \\
\text { (Netherlands, 2011) }\end{array}$ & $\begin{array}{l}\text { human } \\
\text { consumption }\end{array}$ & $118,000^{\mathrm{a}}$ & $\mathrm{n} / \mathrm{a}$ & $\mathrm{n} / \mathrm{a}$ & $\mathrm{n} / \mathrm{a}$ \\
\hline & & $\begin{array}{l}\text { Report on protein } \\
\text { transition }\end{array}$ & $\begin{array}{l}\text { Price analysis } \\
\text { Worldbank } 2011\end{array}$ & $\mathrm{n} / \mathrm{a}$ & $\mathrm{n} / \mathrm{a}$ & $\mathrm{n} / \mathrm{a}$ & 4,750 & $\mathrm{n} / \mathrm{a}$ \\
\hline
\end{tabular}


Table 4. Research context and economic figures for Tenebrio molitor production. ${ }^{1}$

\begin{tabular}{|c|c|c|c|c|c|c|c|c|}
\hline \multirow{2}{*}{$\begin{array}{l}\text { Source } \\
\\
\begin{array}{l}\text { Refereed } \\
\text { literature }\end{array}\end{array}$} & \multicolumn{4}{|l|}{ Research context } & \multicolumn{3}{|c|}{ Price ( $€ /$ tonne of product) } & \multirow{2}{*}{$\begin{array}{l}\text { Operational } \\
\text { costs ( } € / \text { tonne } \\
\text { of fresh larvae) }\end{array}$} \\
\hline & Country & Study method & $\begin{array}{l}\text { Underlying source of } \\
\text { economic figures }\end{array}$ & $\begin{array}{l}\text { Targeted } \\
\text { end-market }\end{array}$ & $\begin{array}{l}\text { Dried } \\
\text { larvae }\end{array}$ & $\begin{array}{l}\text { Larvae } \\
\text { meal }\end{array}$ & $\begin{array}{l}\text { Fresh } \\
\text { larvae }\end{array}$ & \\
\hline \multirow[t]{2}{*}{$\begin{array}{l}\text { Mancuso et } \\
\text { al., } 2019\end{array}$} & Italy & $\begin{array}{l}\text { SWOT analysis } \\
\text { of } 28 \text { European } \\
\text { insect companies }\end{array}$ & $\begin{array}{l}\text { Company data - } \\
\text { Krecafeed (Proti-farm, } \\
\text { 2019) }\end{array}$ & pet food & $\mathrm{n} / \mathrm{a}$ & $\mathrm{n} / \mathrm{a}$ & 10,850 & $\mathrm{n} / \mathrm{a}$ \\
\hline & & & $\begin{array}{l}\text { Company data - } \\
\text { Krecafeed (Proti-farm, } \\
\text { 2019) }\end{array}$ & $\mathrm{n} / \mathrm{a}$ & $\mathrm{n} / \mathrm{a}$ & $\mathrm{n} / \mathrm{a}$ & $17,000^{\mathrm{a}}$ & $\mathrm{n} / \mathrm{a}$ \\
\hline \multirow[t]{2}{*}{$\begin{array}{l}\text { Ortiz et al., } \\
2016\end{array}$} & European Union & Literature review & $\begin{array}{l}\text { Retail prices of insects } \\
\text { for food (2015) }\end{array}$ & $\begin{array}{l}\text { human } \\
\text { consumption }\end{array}$ & 45,454 & $\mathrm{n} / \mathrm{a}$ & $\mathrm{n} / \mathrm{a}$ & $\mathrm{n} / \mathrm{a}$ \\
\hline & China & & & $\begin{array}{l}\text { human } \\
\text { consumption }\end{array}$ & 5,727 & $\mathrm{n} / \mathrm{a}$ & $\mathrm{n} / \mathrm{a}$ & $\mathrm{n} / \mathrm{a}$ \\
\hline $\begin{array}{l}\text { Rumpold and } \\
\text { Schlüter, } \\
2013\end{array}$ & Germany & Literature review & Commercial website & $\begin{array}{l}\text { human } \\
\text { consumption }\end{array}$ & $32,330^{b}$ & $\mathrm{n} / \mathrm{a}$ & $\mathrm{n} / \mathrm{a}$ & $\mathrm{n} / \mathrm{a}$ \\
\hline Other & & & & & & & & \\
\hline \multirow[t]{2}{*}{$\begin{array}{l}\text { Meuwissen, } \\
2011\end{array}$} & Netherlands & $\begin{array}{l}\text { Market-analysis } \\
\text { report }\end{array}$ & $\begin{array}{l}\text { Retail price (The } \\
\text { Netherlands, 2011) }\end{array}$ & $\begin{array}{l}\text { human } \\
\text { consumption }\end{array}$ & $97,000^{\mathrm{a}}$ & $\mathrm{n} / \mathrm{a}$ & 15,800 & $\mathrm{n} / \mathrm{a}$ \\
\hline & & & $\begin{array}{l}\text { (De Bakker and } \\
\text { Dagevos, 2010) }\end{array}$ & $\mathrm{n} / \mathrm{a}$ & $\mathrm{n} / \mathrm{a}$ & $\mathrm{n} / \mathrm{a}$ & $\mathrm{n} / \mathrm{a}$ & $1,090^{c} ; 2,140^{d}$ \\
\hline
\end{tabular}

\section{Profitability of Acheta domesticus production}

Economic figures for the production of $A$. domesticus are presented in Table 5, consisting largely of sales prices for A. domesticus meal and fresh product. The only sales price available for dried product is high relative to the other processing formats. Sales prices for A. domesticus range from $€ 18,182$ to $€ 84,590$ per tonne of product. The lower prices are largely from Thailand, where operational costs are generally low. The Thai market for A. domesticus is also well-known and further developed. Remarkably, the sales prices obtained from Morales-Ramos et al. (2020), which originated from the United States of America, are quite high compared to those reported by Reverberi (2020) who also includes sales prices from this region. MoralesRamos et al. (2020) note that the costs presented in their study do not include the costs of labour or diet mixing. Three different articles present sales prices for fresh $A$. domesticus sold in Thailand, ranging from $€ 1,867$ to $€ 3,952$ per tonne of product. The authors attribute this price range to price decreases over time due to increasing competition. In addition, prices are higher in rural areas than they are in urban areas, with differences between small and largescale farms.

With regard to operational costs, Morales-Ramos et al. (2020) investigate different feeding substrates for crickets and their associated feed costs, with an average of $€ 5,914$ per tonne. Higher feed costs are not always reflected in higher prices. For example, the feeding substrate with the highest feed costs yields the lowest revenue. It should be noted, however, that the prices for four similar feed formulations are relatively low compared to a special type of formulation. No data could be found on operational costs other than feed. In a general comment, however, MoralesRamos et al. (2020) note that the costs of mass-production are high, due to the primitive production techniques that are used, which involve a high amount of labour. In addition, the production of $A$. domesticus requires expensive commercial feed substrates. 
Table 5. Research context and economic figures for Acheta domesticus production. ${ }^{1}$

\begin{tabular}{|c|c|c|c|c|c|c|c|c|}
\hline \multirow{2}{*}{$\begin{array}{l}\text { Article } \\
\\
\begin{array}{l}\text { Refereed } \\
\text { literature }\end{array}\end{array}$} & \multicolumn{4}{|c|}{ Research context } & \multicolumn{3}{|c|}{ Price ( $€ /$ tonne of product) } & \multirow{2}{*}{$\begin{array}{l}\text { Operational } \\
\text { costs } \\
\text { (€/tonne of } \\
\text { larvae meal) }\end{array}$} \\
\hline & Country & Study method & $\begin{array}{l}\text { Underlying } \\
\text { source of } \\
\text { economic figures }\end{array}$ & $\begin{array}{l}\text { Targeted } \\
\text { end-market }\end{array}$ & $\begin{array}{l}\text { Dried } \\
\text { A. domesticus }\end{array}$ & $\begin{array}{l}\text { A. domesticus } \\
\text { meal }\end{array}$ & $\begin{array}{l}\text { Fresh } \\
\text { A. domesticus }\end{array}$ & \\
\hline $\begin{array}{l}\text { Halloran et } \\
\text { al., } 2016\end{array}$ & Thailand & $\begin{array}{l}\text { Assessment of actors } \\
\text { in the cricket industry }\end{array}$ & $\begin{array}{l}\text { Sales prices } \\
\text { Thailand }\end{array}$ & $\begin{array}{l}\text { human } \\
\text { consumption }\end{array}$ & $\mathrm{n} / \mathrm{a}$ & 26,363 & $1,867-3,952$ & $\mathrm{n} / \mathrm{a}$ \\
\hline $\begin{array}{l}\text { Halloran et } \\
\text { al., } 2017\end{array}$ & Thailand & $\begin{array}{l}\text { Analysis impact of } \\
\text { cricket farming on } \\
\text { livelihood }\end{array}$ & $\begin{array}{l}\text { Sales prices from } \\
\text { five Northern } \\
\text { provinces } \\
\text { Thailand }\end{array}$ & $\begin{array}{l}\text { human } \\
\text { consumption }\end{array}$ & $\mathrm{n} / \mathrm{a}$ & $\mathrm{n} / \mathrm{a}$ & $2,018-2,950$ & $\mathrm{n} / \mathrm{a}$ \\
\hline $\begin{array}{l}\text { Hanboonsong } \\
\text { et al., } 2013\end{array}$ & Thailand & $\begin{array}{l}\text { Review of primary } \\
\text { and secondary } \\
\text { interview data }\end{array}$ & $\begin{array}{l}\text { Sales prices from } \\
\text { Thailand }\end{array}$ & $\begin{array}{l}\text { human } \\
\text { consumption }\end{array}$ & $\mathrm{n} / \mathrm{a}$ & $\mathrm{n} / \mathrm{a}$ & $2,363-3,272$ & $\mathrm{n} / \mathrm{a}$ \\
\hline $\begin{array}{l}\text { Morales- } \\
\text { Ramos et } \\
\text { al., } 2020\end{array}$ & USA & $\begin{array}{l}\text { Feeding trial with } \\
\text { different feed } \\
\text { formulations }\end{array}$ & $\begin{array}{l}\text { Average sales } \\
\text { price of nine } \\
\text { companies; feed } \\
\text { costs based on } \\
\text { internet prices }\end{array}$ & $\mathrm{n} / \mathrm{a}$ & $\mathrm{n} / \mathrm{a}$ & 84,590 & $\mathrm{n} / \mathrm{a}$ & $5,914^{a, b}$ \\
\hline \multirow[t]{4}{*}{$\begin{array}{l}\text { Reverberi, } \\
2020\end{array}$} & Canada & $\begin{array}{l}\text { Review on the } \\
\text { development of } \\
\text { cricket farming }\end{array}$ & Cricket Farm Inc. & $\mathrm{n} / \mathrm{a}$ & $\mathrm{n} / \mathrm{a}$ & 18,182 & $\mathrm{n} / \mathrm{a}$ & $\mathrm{n} / \mathrm{a}$ \\
\hline & USA & & $\begin{array}{l}\text { Founder of Aspire } \\
\text { Food Group }\end{array}$ & $\mathrm{n} / \mathrm{a}$ & $\mathrm{n} / \mathrm{a}$ & 36,364 & $\mathrm{n} / \mathrm{a}$ & $\mathrm{n} / \mathrm{a}$ \\
\hline & USA & & $\begin{array}{l}\text { USA cricket } \\
\text { farming consultant }\end{array}$ & $\begin{array}{l}\text { human } \\
\text { consumption }\end{array}$ & $\mathrm{n} / \mathrm{a}$ & 30,000 & $\mathrm{n} / \mathrm{a}$ & $\mathrm{n} / \mathrm{a}$ \\
\hline & Belgium & & $\begin{array}{l}\text { Founder of the } \\
\text { Belgian edible } \\
\text { insect association }\end{array}$ & $\mathrm{n} / \mathrm{a}$ & 45,455 & $\mathrm{n} / \mathrm{a}$ & $\mathrm{n} / \mathrm{a}$ & $\mathrm{n} / \mathrm{a}$ \\
\hline \multicolumn{9}{|l|}{ Other } \\
\hline $\begin{array}{l}\text { Meuwissen, } \\
2011\end{array}$ & $\begin{array}{l}\text { The } \\
\text { Netherlands }\end{array}$ & $\begin{array}{l}\text { Market-analysis } \\
\text { report }\end{array}$ & $\begin{array}{l}\text { Retail price } \\
\text { (The Netherlands, } \\
\text { 2011) }\end{array}$ & $\begin{array}{l}\text { human } \\
\text { consumption }\end{array}$ & $200,000^{c}$ & $\mathrm{n} / \mathrm{a}$ & $\mathrm{n} / \mathrm{a}$ & $\mathrm{n} / \mathrm{a}$ \\
\hline
\end{tabular}

\section{Margins}

Based on the prices and average operational costs for H. illucens, T. molitor and A. domesticus production (Table 2-5), the margins are calculated and shown in Table 6. Due to the lack of economic figures on the operational costs of $A$. diaperinus production, it was not possible to calculate the margin for this insect species. The energy, feed, and labour margin for production of H. illucens is $€-798$ to 15,576 per tonne of dried larvae. The feed and labour margin for production of T. molitor was $€ 7,620$ to 13,770 per tonne of fresh larvae. The feed margin for production of $A$. domesticus was $€ 12,268$ to 78,676 per tonne of larvae meal.

Since prices differ between the specified end-markets, individual margins are calculated. The operational costs are composed of different components, as for T. molitor only feed and labour are included, and for A. domesticus production only feed. Regarding the prices, some prices (i.e. retail prices) refer to prices further along the supply chain, but are used as proxies for sales prices. Sales prices are 
Table 6. Margins (Energy, feed and labour - Labour and feed - Feed) specified per sales price and estimated margin ranges.

\begin{tabular}{|c|c|c|c|c|c|c|c|}
\hline & $\begin{array}{l}\text { Targeted end } \\
\text { market }\end{array}$ & $\begin{array}{l}\text { Country or } \\
\text { Region (prices) }\end{array}$ & $\begin{array}{l}\text { Operational } \\
\text { costs include }\end{array}$ & Sales price & $\begin{array}{l}\text { Average } \\
\text { operational } \\
\text { costs }\end{array}$ & Margin $^{1}$ & Margin range ${ }^{2}$ \\
\hline \multirow[t]{4}{*}{$\begin{array}{l}\text { Hermetia illucens } \\
\text { (dried larvae) }\end{array}$} & $\begin{array}{l}\text { pet food (small } \\
\text { quantities) }\end{array}$ & Germany & $\begin{array}{l}\text { feed, water, } \\
\text { electricity, } \\
\text { labour, gas. }\end{array}$ & $€ 18,190$ & $€ 2,614$ & $€ 15,576^{a}$ & $€-798-€ 15,576^{a}$ \\
\hline & $\begin{array}{l}\text { pet food (bigger } \\
\text { quantities) }\end{array}$ & Germany & $\begin{array}{l}\text { feed, water, } \\
\text { electricity, } \\
\text { labour, gas }\end{array}$ & $€ 6,500$ & & $€ 3,886^{\mathrm{a}}$ & \\
\hline & $\mathrm{n} / \mathrm{a}$ & European Union & $\begin{array}{l}\text { feed, water, } \\
\text { electricity, } \\
\text { labour, gas }\end{array}$ & $€ 2,500$ & & $€-114^{a}$ & \\
\hline & $\mathrm{n} / \mathrm{a}$ & European Union & $\begin{array}{l}\text { feed, water, } \\
\text { electricity, } \\
\text { labour, gas }\end{array}$ & $€ 1,816$ & & $€-798^{a}$ & \\
\hline \multirow{3}{*}{$\begin{array}{l}\text { Tenebrio molitor } \\
\text { (fresh larvae) }\end{array}$} & $\mathrm{n} / \mathrm{a}$ & European Union & feed, labour & $€ 17,000$ & $€ 3,230$ & $€ 13,770^{b}$ & $€ 7,620 € € 13,770^{b}$ \\
\hline & $\begin{array}{l}\text { human } \\
\text { consumption }\end{array}$ & The Netherlands & feed, labour & $€ 15,800$ & & $€ 12,570^{b}$ & \\
\hline & $\mathrm{n} / \mathrm{a}$ & European Union & feed, labour & $€ 10,850$ & & $€ 7,620^{b}$ & \\
\hline \multirow{4}{*}{$\begin{array}{l}\text { Acheta domesticus } \\
\text { (larvae meal) }\end{array}$} & $\mathrm{n} / \mathrm{a}$ & USA & feed & $€ 84,590$ & $€ 5,914$ & $€ 78,676^{c}$ & $€ 12,268-€ 78,676^{c}$ \\
\hline & $\mathrm{n} / \mathrm{a}$ & USA & feed & $€ 45,455$ & & $€ 30,450^{c}$ & \\
\hline & $\mathrm{n} / \mathrm{a}$ & USA & feed & $€ 30,000$ & & $€ 24,086^{c}$ & \\
\hline & $\mathrm{n} / \mathrm{a}$ & Canada & feed & $€ 18,182$ & & $€ 12,268^{c}$ & \\
\hline
\end{tabular}

1 aEnergy, feed, and labour margin; bfeed and labour margin; ffeed margin.

2 a Energy, feed, and labour margin range; ${ }^{b}$ feed and labour margin range; ${ }^{c}$ feed margin range.

highest for the food market, followed by pet food, and were lowest for (aqua) feed. Also, the size of outlet influences the price, as small sold quantities in niche markets result in higher prices. In addition, a difference is seen in prices between Western and non-Western countries.

\section{Discussion and conclusions}

This review aims to present current data on the profitability of insect production and an overview of the economic figures underlying its profitability. Before stating our conclusions, we discuss the interpretation and content of the economic figures.

The number of available sources from which unique economic data could be obtained is low. In many cases, data were cross-referenced, leading back to the same original sources. It is difficult to assess the reliability of some of these original sources, as they have been retrieved from commercial websites, reports, and other grey literature. To ensure the reliability of our overview, we have only included data from sources which presented original references for economic data.
Second, the research methods and set-ups used in the included studies are heterogenous, and mostly focus on topics other than economics. In particular, prices are investigated primarily within the context of feeding trials or consumer-acceptance studies, which present retail prices (and not sales prices). None of the studies includes factual farm data on operational costs. Such data are based predominantly on hypothetical designs (for $\mathrm{H}$. illucens) and placed within the context of experimental feed trials (for A. domesticus). For this reason, they do not necessarily reflect actual practices. These factors made it also difficult to translate the economic figures into margins. It is also important to note that, for actual farm set-ups, profitability entails more than sales prices and operational costs alone. In addition, it is necessary to consider capital expenditures and financing costs, neither of which is reported in any of the studies. Costs and prices may not necessarily reflect individual farms, instead they provide an overview of the available data ranges. Third, the majority of the studies included in the review present only sales or retail prices. The use of retail prices is likely to result in an overestimation of margins. These prices differed for end-markets too, with in general highest prices for human consumption followed by pet food, and feed. Also, the calculation of 
average operational costs across references was impeded by the scarcity of data on operational costs. For example, the average operational costs for $H$. illucens production could be calculated only based on data obtained from two sources, and only one source was available for T. molitor and A. domesticus. In addition, economic figures obtained for operational costs differed according to the species of insects. For T. molitor and A. domesticus, the literature provides information only on the costs of feed and/or labour, and not on any other material input costs (e.g. electricity, water, gas). These differences in the operational cost items for different studies prevented us from comparing margin ranges across insects species. Therefore, we have calculated individual margins and presented the margins in ranges. The aforementioned considerations should be taken into account when interpreting these margins and their ranges.

Fourth, the prices and feed costs for $A$. domesticus meal are considerably higher than those for H. illucens, A. diaperinus and T. molitor meal. This difference is in line with Brynning et al. (2020), who note that the prices of $A$. diaperinus and T. molitor larvae are lower than those of $A$. domesticus, which might be one of the reasons that they are more attractive for food and feed companies to include in their products. Remarkably, most of the economic figures obtained for $H$. illucens, A. diaperinus, and T. molitor are from Europe and China, while data from $A$. domesticus production originate from the United States of America and Thailand. In general, the literature included in the overview reflects a wide range of sales prices for comparable outputs (e.g. the same processing format for same insects), and they include several outliers.

Our findings on variations in sales prices are in line with the findings of Mancuso et al. (2019), who conclude that sales prices depend on many factors, including size of outlet, insect species, product type (larvae, adult, pupae), chain stage and processing format. It is interesting to note that, with the exception of the article by Morales-Ramos et al. (2020), most of the studies included in this overview provide no information on the quality of feed and dry matter content, which is known to influence the composition and thus the value - of the product (Law and Wein, 2018).

In conclusion, this study provides an up-to-date overview of the profitability of insect production and its underlying economic figures. The margins are based on sales prices and average operational costs, expressed as margin ranges specified for three insect species. Energy, feed and labour margin for H. illucens production, feed and labour margin for $T$. molitor production, and feed margin for $A$. domesticus production are respectively: $€-798$ to 15,576 per tonne of dried larvae, $€ 7,620$ to 13,770 per tonne of fresh larvae and $€ 12,268$ to 78,676 per tonne of meal. Reliable margins for the production of $A$. diaperinus could not be calculated, due to a lack of economic figures on operational costs in the literature. Margin ranges cannot be compared between the different insect species, as they are calculated for different processing formats and include different cost-components. The ranges of margins for all insect species are wide, which can be led back to the wide variety and differences in sales prices.

The reported sales prices depend on geographical location and type of market (i.e. feed, pet food or human consumption), as well as on the quantity sold in niche markets. Sales prices are relatively low in non-Western countries, relative to those in Western countries, which might be related to inter alia lower operational costs in the former. Operational cost is, however, not the only component determining the sales price, as it is also dependent on, for example, the type of market sold and the size of outlet. In general, sales prices for products intended for food are higher than those for products intended for feed. This difference could be due to the higher quality required for food production and the small quantities sold. The price difference over time that has been observed for the production of H. illucens meal could be explained by an increase in competition or technical progress.

The amount of information available with regard to operational costs varies with species. For example, labour costs are subject to differences in the hourly fees applied. Considering the labour-intensive process of insect production, which is related to the low level of mechanisation on most insect farms, these labour costs are seen as an important cost component. Although we could not draw any conclusions on cost-reduction or profit increase of insect production, it has been suggested that increasing levels of mechanisation will reduce labour costs and that the use of low-value feed substrates will reduce operational costs. Regarding the sales of farm output, commercialisation of insect frass as fertiliser could provide an additional source of income for insect farmers. Additional research is nevertheless needed with regard to the additional costs and consequences of larger-scale production. Further research on the profitability of insect farms is also highly recommended, in order to make a constructive contribution to the development of the insect sector and to increase the availability of economic data on insect production. The focus should be on collecting factual farm data, in order to establish an overview of the profitability of practicing farms. First, farm outlet prices are necessary to calculate a reliable gross margin for insect rearing companies. Second, the inclusion of capital expenditures and financing costs in the calculation of profitability would provide a more differentiated calculation at the company level. This would provide farmers with a more reliable source of data to consult when starting new farms, while helping and financial institutions and governments to facilitate access to financing and other services. Another valuable future contribution would be a clear overview of the different 
prices and costs associated with different geographical locations, which could be linked to different production systems. This could help to identify which production systems would be most suitable for which countries (e.g. in terms of the amount of labour needed).

\section{Acknowledgements}

This project has received funding from the European Union's Horizon 2020 research and innovation programme under grant agreement No 861976.

\section{Conflicts of interest}

The authors declare no conflict of interest.

\section{References}

Abdel-Tawwab, M., Khalil, R.H., Metwally, A.A., Shakweer, M.S., Khallaf, M.A. and Abdel-Latif, H.M., 2020. Effects of black soldier fly (Hermetia illucens L.) larvae meal on growth performance, organs-somatic indices, body composition, and hemato-biochemical variables of European sea bass, Dicentrarchus labrax. Aquaculture 522: 735136. https://doi.org/10.1016/j.aquaculture.2020.735136

Aiking, H. and De Boer, J., 2019. Protein and sustainability - the potential of insects. Journal of Insects as Food and Feed 5: 3-7. https://doi.org/10.3920/JIFF2018.0011

Brealey, R.A., 2001. Fundamentals of corporate finance. McGraw Hill, New York, NY, USA.

Brynning, G., Bækgaard, J.U. and Heckmann, L.-H.L., 2020. Investigation of consumer acceptance of foods containing insects and development of non-snack insect-based foods. Industrial Biotechnology 16: 26-32. https://doi.org/10.1089/ind.2019.0028

Chia, S.Y., Tanga, C.M., Osuga, I.M., Alaru, A.O., Mwangi, D.M., Githinji, M., Subramanian, S., Fiaboe, K.K., Ekesi, S. and Van Loon, J.J., 2019. Effect of dietary replacement of fishmeal by insect meal on growth performance, blood profiles and economics of growing pigs in Kenya. Animals 9: 705. https://doi.org/10.3390/ani9100705

De Bakker, H. and Dagevos, H., 2010. Meat lovers, meat miners and meat avoiders: sustainable protein consumption in a carnivorous food culture. Vleesminnaars, vleesminderaars en vleesmijders: duurzame eiwitconsumptie in een carnivore eetcultuur. LEI Wageningen UR, Wageningen, the Netherlands.

Derrien, C. and Boccuni, A., 2018. Current status of the insect producing industry in Europe, Edible insects in sustainable food systems. Springer, Berlin, Germany, pp. 471-479.

Dobermann, D., Swift, J. and Field, L., 2017. Opportunities and hurdles of edible insects for food and feed. Nutrition Bulletin 42: 293-308. https://doi.org/10.1111/nbu.12291

Dossey, A., Tatum, J. and McGill, W., 2016. Modern insect-based food industry: current status, insect processing technology, and recommendations moving forward. Insects as sustainable food ingredients. Elsevier, Amsterdam, the Netherlands, pp. 113-152. https://doi.org/10.1016/B978-0-12-802856-8.00005-3

Halloran, A., Flore, R., Vantomme, P. and Roos, N., 2018. Edible insects in sustainable food systems. Springer, Berlin, Germany.
Halloran, A., Roos, N., Flore, R. and Hanboonsong, Y., 2016. The development of the edible cricket industry in Thailand. Journal of Insects as Food and Feed 2: 91-100. https://doi.org/10.3920/ JIFF2015.0091

Halloran, A., Roos, N. and Hanboonsong, Y., 2017. Cricket farming as a livelihood strategy in Thailand. The Geographical Journal 183: 112-124. https://doi.org/10.1111/geoj.12184.

Hanboonsong, Y., Jamjanya, T. and Durst, P.B., 2013. Six-legged livestock: edible insect farming, collection and marketing in Thailand. Food and Agriculture Organisation of the United Nations, Regional Office for Asia and the Pacific, Bangkok, Thailand, 57 pp.

Heckmann, L.-H., Andersen, J., Eilenberg, J., Fynbo, J., Miklos, R., Jensen, A.N., Nørgaard, J.V. and Roos, N., 2019. A case report on inVALUABLE: insect value chain in a circular bioeconomy. Journal of Insects as Food and Feed 5: 9-13. https://doi.org/10.3920/ JIFF2018.0009

Henchion, M., Hayes, M., Mullen, A.M., Fenelon, M. and Tiwari, B., 2017. Future protein supply and demand: strategies and factors influencing a sustainable equilibrium. Foods 6: 53. https://doi. org/10.3390/foods6070053

Hilkens, W., De Klerk, B. and Van Gestel, D., 2016. Insect farming: small sector with big opportunities. Insectenkweek: kleine sector met grote kansen. ABN AMRO/Brabantse Ontwikkelings Maatschappij, Amsterdam/Tilburg, the Netherlands, 37 pp.

Hillier, D., Ross, S., Westerfield, R., Jaffe, J. and Jordan, B., 2016. Corporate finance. McGraw Hill, New York, NY, USA.

Investing.com, 2020. Exchange rate EUR/USD. Available at: https:// nl.investing.com/currencies/eur-usd

International Platform of Insects for Food and Feed (IPIFF), 2019. The European insect sector today: challenges, opportunities and regulatory landscape. IPIFF vision paper on the future of the insect sector towards 2030. IPIFF, Brussels, Belgium.

International Platform of Insects for Food and Feed (IPIFF), 2020a. Edible insects on the European Market. IPIFF, Brussels, Belgium. International Platform of Insects for Food and Feed (IPIFF), 2020b. The insect sector milestones towards sustainable food supply chains. IPIFF, Brussels, Belgium.

Ites, S., Smetana, S., Toepfl, S. and Heinz, V., 2020. Modularity of insect production and processing as a path to efficient and sustainable food waste treatment. Journal of Cleaner Production 248: 119248. https://doi.org/10.1016/j.jclepro.2019.119248

Jensen, K., Kristensen, T.N., Heckmann, L.-H. and Sørensen, J.G., 2017. Breeding and maintaining high-quality insects. In: Van Huis, A. and Tomberlin, J.K. (eds.) Insects as food and feed: from production to consumption. Wageningen Academic Publishers, Wageningen, the Netherlands, pp. 174-198.

Kelemu, S., Niassy, S., Torto, B., Fiaboe, K., Affognon, H., Tonnang, H., Maniania, N. and Ekesi, S., 2015. African edible insects for food and feed: inventory, diversity, commonalities and contribution to food security. Journal of Insects as Food and Feed 1: 103-119. https:// doi.org/10.3920/JIFF2014.0016

Law, Y. and Wein, L., 2018. Reversing the nutrient drain through urban insect farming - opportunities and challenges. Bioengineering 5: 226-237. https://doi.org/10.3934/bioeng.2018.4.226 
Llagostera, P.F., Kallas, Z., Reig, L. and De Gea, D.A., 2019. The use of insect meal as a sustainable feeding alternative in aquaculture: current situation, Spanish consumers' perceptions and willingness to pay. Journal of Cleaner Production 229: 10-21. https://doi. org/10.1016/j.jclepro.2019.05.012

Macombe, C., Le Feon, S., Aubin, J. and Maillard, F., 2019. Marketing and social effects of industrial scale insect value chains in Europe: case of mealworm for feed in France. Journal of Insects as Food and Feed 5: 215-224. https://doi.org/10.3920/JIFF2018.0047

Mancuso, T., Pippinato, L. and Gasco, L., 2019. The European insects sector and its role in the provision of green proteins in feed supply. Calitatea 20: 374-381.

Marberg, A., Van Kranenburg, H. and Korzilius, H., 2017. The big bug: the legitimation of the edible insect sector in the Netherlands. Food Policy 71: 111-123. https://doi.org/10.1016/j.foodpol.2017.07.008

Marcucci, C., 2020. Food frontiers: Insects as food, is the future already here? Mediterranean Journal of Nutrition and Metabolism 13(1): 43-52. https://doi.org/10.3233/MNM-190348

Meuwissen, P., 2011. Insects as new protein source. A scenario exploration of market opportunities. Insecten als nieuwe eiwitbron. Een scenarioverkenning van de marktkansen. ZLTO, 's Hertogenbosch, the Netherlands.

Morales-Ramos, J.A., Rojas, M.G., Dossey, A.T. and Berhow, M., 2020. Self-selection of food ingredients and agricultural by-products by the house cricket, Acheta domesticus (Orthoptera: Gryllidae): a holistic approach to develop optimized diets. PLoS ONE 15: e0227400. https://doi.org/10.1371/journal.pone.0227400

Oonincx, D., 2017. Environmental impact of insect production. In: Van Huis, A. and Tomberlin, J.K. (eds.) Insects as food and feed: from production to consumption. Wageningen Academic Publishers, Wageningen, the Netherlands, pp. 79-93.

Ortiz, J.C., Ruiz, A.T., Morales-Ramos, J., Thomas, M., Rojas, M., Tomberlin, J., Yi, L., Han, R., Giroud, L. and Jullien, R., 2016. Insect mass production technologies. In: Rojas, M.G., Morales-Ramos, J.A. and Dossey, A.T. (eds.) Insects as sustainable food ingredients. Elsevier, Amsterdam, the Netherlands, pp. 153-201.
Pleissner, D. and Smetana, S., 2020. Estimation of the economy of heterotrophic microalgae-and insect-based food waste utilization processes. Waste Management 102: 198-203. https://doi. org/10.1016/j.wasman.2019.10.031

Raheem, D., Carrascosa, C., Oluwole, O.B., Nieuwland, M., Saraiva, A., Millán, R. and Raposo, A., 2019. Traditional consumption of and rearing edible insects in Africa, Asia and Europe. Critical Reviews in Food Science and Nutrition 59: 2169-2188. https://doi.org/10.1 080/10408398.2018.1440191

Research and Markets, 2019. Insect feed market - growth, trends and forecasts (2020-2025). Available at: https://www. researchandmarkets.com/reports/4904389/insect-feed-marketgrowth-trends-and-forecasts

Reverberi, M., 2020. Edible insects: cricket farming and processing as an emerging market. Journal of Insects as Food and Feed 6: 211-220. https://doi.org/10.3920/JIFF2019.0052

Roos, N. and Van Huis, A., 2017. Consuming insects: are there health benefits? Journal of Insects as Food and Feed 3: 225-229. https:// doi.org/10.3920/JIFF2017.x007

Rumpold, B.A. and Schlüter, O.K., 2013. Potential and challenges of insects as an innovative source for food and feed production. Innovative Food Science \& Emerging Technologies 17: 1-11. https:// doi.org/10.1016/j.ifset.2012.11.005

Sogari, G., Amato, M., Biasato, I., Chiesa, S. and Gasco, L., 2019. The potential role of insects as feed: a multi-perspective review. Animals 9: 119. https://doi.org/10.3390/ani9040119

Van der Fels-Klerx, H., Camenzuli, L., Belluco, S., Meijer, N. and Ricci, A., 2018. Food safety issues related to uses of insects for feeds and foods. Comprehensive Reviews in Food Science and Food Safety 17: 1172-1183. https://doi.org/10.1111/1541-4337.12385

Van Huis, A., 2020. Insects as food and feed, a new emerging agricultural sector: a review. Journal of Insects as Food and Feed 6: 27-44. https://doi.org/10.3920/JIFF2019.0017 